\title{
Experiment for Arsenic Accumulation into Rice Cultivated with Arsenic Enriched Irrigation Water in Bangladesh
}

\author{
M.A.K. Azad ${ }^{1}$, A.H.M.F.K. Monda, I. Hossain ${ }^{2}$, M. Moniruzzaman ${ }^{3}$ \\ ${ }^{1}$ Institute of Environmental Science, Rajshahi University, Rajshahi, Bangladesh \\ ${ }^{2}$ Department of Geology and Mining, Rajshahi University, Rajshahi, Bangladesh \\ ${ }^{3}$ Department of Geography and Environmental Studies, Rajshahi University, Rajshahi, Bangladesh \\ *Corresponding author: akazad_ies@yahoo.com
}

Received May 10, 2013; Revised June 20, 2013; Accepted June 22, 2013

\begin{abstract}
A green house field experiment of rice (Oryza sativa L) with arsenic amended irrigation water was conducted at Institute of Environmental Science of Rajshahi University to observe the trend of arsenic (As) accumulation into rice and soil. Sodium arsenate $\left(\mathrm{Na}_{2} \mathrm{HAsO}_{4}\right)$ amended irrigation water $(0.0,0.1,0.5,1.0,2.0$ and $4.0 \mathrm{mg} / \mathrm{l} \mathrm{As}$ ) was used for cultivating a popular HYV-aman rice variety named BR-11. Arsenic accumulation of rice straw, grain and soil were investigated. A significant $(\mathrm{p} \leq 0.01)$ increasing trend of arsenic accumulation in straw, grain and soil was found with increase of arsenic in irrigation water. The highest level of arsenic in straw, grain and soil was observed in the treatment of $4.0 \mathrm{mg} / \mathrm{l}$ As containing irrigation water and lowest level in control treatment. Arsenic in irrigation water showed a strong positive correlations with arsenic accumulation into soil, straw and grain, and the trend of accumulation was found as water $>$ soil $>$ straw $>$ grain.
\end{abstract}

Keywords: arsenic, water, soil, rice

\section{Introduction}

Rice is the staple food for nearly $50 \%$ of the world population [1] and Asia represents about $90 \%$ of global rice production and consumption. Bangladesh is the world's 6th largest rice producer where people get more than $70 \%$ of their calorie from staple food rice, providing carbohydrate, and some other proteins, vitamins and minerals [2]. The agricultural economy of Bangladesh is deeply dependent on rice. It is estimated that almost threequarters of total cropped land in Bangladesh is devoted to paddy cultivation, and per capita rice consumption is one of the highest in the world. Based on national surveys, food grain consumption for an average person in urban and rural areas in Bangladesh is shown to have stabilized over time at about 160 and $180 \mathrm{~kg}$ per person per year, respectively [3]. Rice is the main food grain product and it is estimated that rice expenditures make up $40 \%$ of total food expenditures [3]. In order to cope with the increasing population, food security, nutrition, urbanization, climate change, Bangladesh Rice Research Institute (BRRI) has introduced many high yielding rice varieties and till today they have released 57 new varieties which are growing in three different seasons namely Aush, Aman and Boro. Aman is the main monsoon season in Bangladesh (July to November) and Aush is a short season (April to May) that follows the dry season or Boro (November/December to April/May) [2]. Significant changes have happened to rice cultivation in Bangladesh over time. Aman acreage has changed little over time, but Boro acreage has increased substantially and Aus acreage has declined accordingly [4]. Production of rice overall has increased significantly over the last 40 years. Due to the proliferation of shallow tube wells and the development of high-yielding dry-season rice varieties (Boro rice), rice yields have increased dramatically and the share of dry-season rice has increased from $10 \%$ of the country's rice production in 1966-67 to $61 \%$ in 2008 [5]. The country has shifted from chronic food shortages to self sufficiency by the mid-1990's [6]. Rice covers about $83 \%$ of the irrigated area in Bangladesh [7]. Sixty of 64 districts are affected by groundwater arsenic contamination [8]. Geographically four unaffected districts are located in the old alluvial and mountain terrace soil area. Whereas soils of sixty districts of Bangladesh form by the process of alluvial deposition during monsoon river water. This young soil is badly affected with arsenic. Therefore, the Occurrences of arsenic (As) in the Bengal Basin of Bangladesh show close relationships with depositional environments and sediment textures [9]. The enrichment of groundwater by As is restricted mainly to the Holocene alluvial and deltaic plains of the Bengal Basin, whereas groundwater abstracted from the older Plio-Pleistocene aquifers are characteristically low in As. The Holocene shallow aquifers at the lower reach of the Ganges-BrahmaputraMeghna (GBM) river system are most severely affected compared to other geological settings which show the distinct regional pattern of Arsenic [10]. Mobilisation of As into the groundwater of shallow alluvial aquifers in the Bengal Basin through natural processes involving 
reductive dissolution of Fe-oxyhydroxide is widely accepted as the principal mechanism [11]. The farmers of Bangladesh irrigate their crops with arsenic contaminated ground water. The use of arsenic contaminated ground water in irrigation for a prolong period of time may increase the concentrations of arsenic in soil and crops [12]. The paddy soil gets contaminated from the irrigation water and thus enhancing the bioaccumulation of arsenic in rice plants [13]. Elevated arsenic concentrations in rice grain were found from many parts of Bangladesh [14]. Variation in rice grain arsenic concentration in Bangladesh was largely controlled by rice genetics [15]. The accumulation of arsenic in rice plants also varied with different variety of rice [16]. Mean arsenic concentration for boro rice $(183 \mu \mathrm{g} / \mathrm{kg})$ was 1.5 times higher than aman rice $(117 \mu \mathrm{g} / \mathrm{kg})$ [17]. Rice grain accumulated relatively large amounts of arsenic from soils which not contaminated by arsenic [18].

However, limited research has been done on the trend of arsenic accumulation into soil and rice in Gangetic soil condition of Bangladesh. Detailed information is needed for the conclusive assessment on the use of arsenic contaminated irrigation water and its accumulation into rice. The aim of this study was to assess the accumulation of arsenic into rice in Gangetic soil condition. Therefore, this research work was carried out to find out the trend of arsenic accumulation into soil and rice as well as to find out a safe level of arsenic in irrigation water for rice cultivation in Bangladesh.

\section{Materials and Methods}

\subsection{Experimental Site}

This field experiment was conducted in a green house made of transparent poly-ethylene paper, situated within $24^{\circ} 22^{\prime} 10.2^{\prime \prime}$ to $24^{\circ} 22^{\prime} 10.3^{\prime \prime} \mathrm{N}$ and $88^{\circ} 38^{\prime} 21.7^{\prime \prime}$ to $88^{\circ} 38^{\prime} 21.8^{\prime \prime} \mathrm{E}$ at Institute of Environmental Science of Rajshahi University in north-western part of Bangladesh during August to December 2011. The study site has subtropical and humid climate with adequate sunshine during day time.

\subsection{Soil Condition}

The experiment was conducted in gangetic soil condition. The properties of soil were total Nitrogen $0.04 \pm 0.02 \%$, available P $25.3 \pm 0.04$ ppm, available $\mathrm{K}$ $0.21 \pm 0.03 \mathrm{~mol} / \mathrm{kg}$, available S $15.7 \pm 0.05 \mathrm{ppm}$, available Z $0.68 \pm 0.04 \mathrm{ppm}, \mathrm{pH} 7.7 \pm 0.03$, organic matter $0.80 \pm 0.05$ and background total arsenic (As) 5.60 $\pm 0.05 \mathrm{ppm}$.

\subsection{Rice Variety}

Rice variety, BR-11 is very popular aman variety in Bangladesh. This rice variety was cultivated for this experiment.

\subsection{Seedling Transplantation}

Thirty-five days old seedlings were uprooted carefully from the seedbed in the morning from the Bangladesh Rice Research Institute, Rajshahi station and four seedlings for each hill with three replications were transplanted on the same day in experimental field on 7th
August 2011. The seedlings which died within 6 days of transplantation were discarded and new seedlings were replaced.

\subsection{Intercultural Application}

\subsubsection{Fertilizer Application}

To support the plant growth, urea, triple super phosphate (TSP), murate of potash (MP) and gypsum fertilizer were applied for nitrogen, phosphorus, potassium, and sulfur, respectively. The first spilt (one third of the dose) of urea and full doses of all other fertilizers were incorporated into the soil by hand before two days of seedling transplantation. The second and third splits of urea were applied after 30 (maximum tillering stage) and 70 (panicle initiation stage) days of transplantation, respectively. One insecticide named fighter was applied into the soil to kill the insects and aphids those attacked the rice plants.

\subsubsection{Arsenic Source}

Sodium arsenate $\left(\mathrm{Na}_{2} \mathrm{HAsO}_{4}\right)$ was used for arsenic source.

\subsubsection{Irrigation and Treatment}

Six arsenic treatments $0.0,0.1,0.5,1.0,2.0$, and 4.0 $\mathrm{mg} / \mathrm{L}$ As containing irrigation water were used in this experiment. After transplantation of rice seedlings, 3-4 cm water above soil level was maintained in each treatment throughout the growth period. Irrigation was stopped before 10 days of harvest.

\subsection{Sample Collection and Preservation}

The rice plants were cut at $4 \mathrm{~cm}$ above the soil. Rice grain was harvested at their maturity stage (120 days after transplantation) on 7th December 2011. Then the collected samples (straw and rice grain) from each treatment were tagged properly and sun dried for 3 days and then keeping the samples on a wooden table. The sun dried samples were stored in a drying cabinet at $45^{\circ} \mathrm{C}$.

\subsection{Chlorophyll Measurement}

The chlorophyll from rice leaves during flowering stage was extracted in $80 \%$ acetone and chlorophyll contents were measured at $663 \mathrm{~nm}$ and $645 \mathrm{~nm}$ in a spectrophotometer. From the absorption coefficients, the amount of chlorophyll was calculated.

\subsection{Arsenic Analysis}

Soil, rice straw and grain samples were digested separately following the heating block digestion procedure [19]. Rice straw and grain samples were digested by $\mathrm{HNO}_{3}-\mathrm{HClO}_{4}$ and soil samples by $\mathrm{HNO}_{3}-\mathrm{H}_{2} \mathrm{SO}_{4}-\mathrm{HClO}_{4}$ for measuring arsenic concentrations in hydride generation atomic absorption spectrophotometer in BCSIR Laboratory, Dhaka.

\subsection{Statistical Analysis}

The analysis of variance (ANOVA) was done following the F-statistics. Duncan's multiple range test (DMRT) was used for mean comparisons of the treatment at $5 \%$ level of 
probability. Pearson correlation coefficients among the parameters were also calculated.

\section{Results and Discussion}

\subsection{Chlorophyll Contents}

Soil arsenic concentrations showed negative correlations with the chlorophyll-a and chlorophyll-b contents in rice leaf [20]. We found that chlorophyll-a and chlorophyll-b content in rice leaf was decreased significantly ( $p=0.0022$ and $p=0.0006$, respectively) with increase of arsenic concentration in irrigation water. The highest and lowest chlorophyll-a and chlorophyll-b contents in leaves of BR-11 rice were found in $0.1 \mathrm{mg} / \mathrm{l}$ and in $4 \mathrm{mg} / \mathrm{l}$ As treatment, respectively (Table 1). Moreover, we observed a significant $(\mathrm{p}<0.01)$ strong negative correlation $(r=-0.78)$ between chlorophyll-a content and irrigation water arsenic. A significant ( $\mathrm{p}<$ 0.01) strong negative correlation $(r=-0.77)$ between chlorophyll-b content and irrigation water arsenic was also found.

Table 1. Effect of arsenic amended irrigation water on chlorophyll contents of BR-11 rice leaves.

\begin{tabular}{|c|c|c|}
\hline \multirow{2}{*}{$\begin{array}{l}\text { Arsenic added in water } \\
\text { (mg/l) }\end{array}$} & \multicolumn{2}{|c|}{ Chlorophyll contents (mg/g) } \\
\hline & Chlorophyll- $a$ & Chlorophyll- $b$ \\
\hline 0.0 & $20.27 \pm 1.70 \mathrm{ab}$ & $17.00 \pm 1.84 b$ \\
\hline 0.1 & $24.84 \pm 0.39 a$ & $21.57 \pm 0.73 a$ \\
\hline 0.5 & $20.18 \pm 1.14 \mathrm{ab}$ & $15.53 \pm 0.47 b c$ \\
\hline 1 & $16.11 \pm 2.68 \mathrm{bc}$ & $12.29 \pm 2.04 \mathrm{~cd}$ \\
\hline 2 & $15.90 \pm 2.97 \mathrm{bc}$ & $12.16 \pm 2.04 \mathrm{~cd}$ \\
\hline 4 & $10.91 \pm 0.66 c$ & $08.46 \pm 0.03 d$ \\
\hline F-test & $* *$ & $* *$ \\
\hline
\end{tabular}

Same letters in a column did not differ significantly at $\mathrm{p} \leq 0.05$ by DMRT; ** indicate significant at 0.01 level of probability.

\subsection{Spikelet Number}

The number of filled spikelet pot-1 decreased significantly ( $p<0.001$ ) with the level of arsenate contaminated irrigation water [21]. We also found that filled spikelet number of BR-11 rice decreased significantly $(\mathrm{p}=0.0019)$ with increase of arsenic concentration in irrigation water. The highest filled spikelet number $(678.33 \pm 78.81)$ was found in control treatment and the lowest $(197.33 \pm 97.58)$ in $4 \mathrm{mg} / \mathrm{l} \mathrm{As}$ treatment (Table 2). The highest filled spikelet number was also observed in control treatment [21]. A significant $(p<0.05)$ negative correlation $(r=-0.552)$ between filled spikelet number and irrigation water arsenic was detected.

Empty spikelet number was increased insignificantly with increase of arsenic concentration in irrigation water (Table 2). Empty spikelet number showed an insignificant positive correlation $(r=0.127)$ with irrigation water arsenic. Total spikelet number was decreased insignificantly with increase of arsenic concentration in irrigation water (Table 2). Total spikelet number showed an insignificant negative correlation $(r=-0.315)$ with irrigation water arsenic.
Table 2. Effect of arsenic amended irrigation water on Spikelet number of BR-11 rice

\begin{tabular}{|c|c|c|c|}
\hline $\begin{array}{c}\text { Arsenic } \\
\text { added in } \\
\text { water }(\mathrm{mg} / \mathrm{l})\end{array}$ & $\begin{array}{c}\text { Filled spikelet } \\
\text { number }\end{array}$ & $\begin{array}{c}\text { Empty spikelet } \\
\text { number }\end{array}$ & $\begin{array}{c}\text { Total spikelet } \\
\text { number }\end{array}$ \\
\hline 0.0 & $\begin{array}{c}1091.67 \pm \\
206.10 \mathrm{a}\end{array}$ & $\begin{array}{c}1083.33 \pm \\
123.47 \mathrm{a}\end{array}$ & $\begin{array}{c}2172.00 \pm \\
332.07 \mathrm{a}\end{array}$ \\
\hline 0.1 & $\begin{array}{c}678.33 \pm \\
78.81 \mathrm{~b}\end{array}$ & $\begin{array}{c}945.00 \pm \\
120.45 a\end{array}$ & $\begin{array}{c}1623.33 \pm \\
81.67 a\end{array}$ \\
\hline 0.5 & $\begin{array}{c}270.00 \pm \\
116.21 \mathrm{c} \\
\end{array}$ & $\begin{array}{c}1203.33 \pm \\
26.82 \mathrm{a} \\
\end{array}$ & $\begin{array}{c}1473.33 \pm \\
126.07 \mathrm{a}\end{array}$ \\
\hline 1 & $\begin{array}{c}243.33 \pm \\
138.51 \mathrm{c}\end{array}$ & $\begin{array}{c}1208.00 \pm \\
212.28 \mathrm{a}\end{array}$ & $\begin{array}{c}1451.33 \pm \\
131.13 a\end{array}$ \\
\hline 2 & $\begin{array}{c}216.33 \pm \\
108.41 c\end{array}$ & $\begin{array}{c}1230.00 \pm \\
599.88 a\end{array}$ & $\begin{array}{c}1446.33 \pm \\
616.68 \mathrm{a}\end{array}$ \\
\hline 4 & $\begin{array}{c}197.33 \pm \\
97.58 c \\
\end{array}$ & $\begin{array}{c}1185.00 \pm \\
80.47 \mathrm{a} \\
\end{array}$ & $\begin{array}{c}1382.33 \pm \\
107.54 \mathrm{a} \\
\end{array}$ \\
\hline F-test & $* *$ & - & - \\
\hline
\end{tabular}

Same letters in a column did not differ significantly at $\mathrm{p} \leq 0.05$ by DMRT; ** indicate significant at 0.01 level of probability.

\subsection{Arsenic Accumulation in Soil}

The arsenic concentration in soil of BR-11 paddy field was $5.60 \mathrm{mg} / \mathrm{kg}$. Arsenic accumulation in paddy soil was increased significantly ( $\mathrm{p} \leq 0.01)$ with increase of arsenic concentration in irrigation water (Table 3 ). The average arsenic concentration in Faridpur district of Bangladesh was more than three times higher than the world standard (10 $\mathrm{mg} / \mathrm{kg})$ [22]. We found that up to $1 \mathrm{mg} / \mathrm{l} \mathrm{As}$ in irrigation water, the soil arsenic not exceeded the world standard but thereafter arsenic concentration in paddy soil was found higher than the world standard for soil (Table 3). A significant $(\mathrm{p}<0.01)$ strong positive correlation $(\mathrm{r}=$ 0.90) between irrigation water arsenic and arsenic accumulation in paddy soil was observed (Table 4).

\subsection{Arsenic Accumulation in Straw}

A significant increase of arsenic in rice straw with increase of arsenate concentrations in irrigation water was reported [23]. In this study arsenic accumulation in straw of BR-11 rice was found to increase significantly ( $p \leq$ 0.01 ) with increase of arsenic concentration in irrigation water (Table 3). An elevated arsenic concentration in rice straw (up to $149 \mathrm{mg} / \mathrm{kg}$ As by dry weight) was detected when rice was grown in soil amended with sodium arsenate at different levels (0-312.5 mg/kg As) [24]. Ricestraw arsenic content increased with increasing of soilarsenic concentration was also reported [25]. Straw accumulated twice as much arsenic than the grain [26]. We also found that arsenic accumulation in straw was much higher than grain. The highest arsenic accumulation was found in straw $(4.69 \pm 0.14 \mathrm{mg} / \mathrm{kg})$ in $4 \mathrm{mg} / \mathrm{l}$ treatment and lowest $(1.72 \pm 0.16 \mathrm{mg} / \mathrm{kg})$ in control (Table 3$)$. As like as soil a significant $(\mathrm{p}<0.01)$ strong positive correlation $(r=0.90)$ between irrigation water arsenic and arsenic accumulation in straw of BR-11 rice was observed (Table 4).

\subsection{Arsenic Accumulation in Grain}

From the arsenic uptake study of T-aman rice, it was found that the arsenic in rice grain increases with increase of arsenic in soil, but did not vary significantly up to $20 \mathrm{mg} / \mathrm{kg}$ As treatment [26]. Arsenic uptake and accumulation 
was greatly affected by arsenic contamination in soil and increased greatly with increasing levels of arsenic [27]. Arsenic in rice grain $(0.30 \mathrm{mg} / \mathrm{kg}$ dry weight $)$ was found when the rice was grown with $2.0 \mathrm{ppm}$ arsenic contaminated irrigation water [23].We also found that arsenic accumulation in grain of BR-11 rice was increased significantly $(\mathrm{p}<0.01)$ with increase of arsenic concentration in irrigation water (Table 3). The highest level of arsenic accumulation in grain $(0.47 \pm 0.03 \mathrm{mg} / \mathrm{kg})$ and the lowest level of arsenic accumulation in grain $(0.06 \pm 0.01 \mathrm{mg} / \mathrm{kg})$ was observed in $4 \mathrm{mg} / \mathrm{l}$ and control treatments, respectively (Table 3).Rice grain generally has lower arsenic concentration and the concentration remains much below the maximum permissible limit of $1 \mathrm{mg} / \mathrm{kg}$ As [28]. Moreover, a significant ( $p<0.01)$ strong positive correlation $(r=0.804)$ between arsenic in irrigation water and arsenic accumulation in grain of BR-11 rice was found (Table 4).

Table 3. Arsenic accumulation in soil, straw and grain of BR-11 rice

\begin{tabular}{|c|c|c|c|}
\hline $\begin{array}{c}\text { Arsenic } \\
\text { added in } \\
\text { water } \\
(\mathrm{mg} / \mathrm{l})\end{array}$ & $\begin{array}{c}\text { Arsenic in soil } \\
(\mathrm{mg} / \mathrm{kg})\end{array}$ & $\begin{array}{c}\text { Arsenic in } \\
\text { straw }(\mathrm{mg} / \mathrm{kg})\end{array}$ & $\begin{array}{c}\text { Arsenic in } \\
\text { grain }(\mathrm{mg} / \mathrm{kg})\end{array}$ \\
\hline 0.0 & $3.67 \pm 0.39 \mathrm{a}$ & $1.72 \pm 0.16 \mathrm{a}$ & $0.06 \pm 0.01 \mathrm{a}$ \\
\hline 0.1 & $6.11 \pm 0.46 \mathrm{~b}$ & $2.96 \pm 0.14 \mathrm{~b}$ & $0.19 \pm 0.01 \mathrm{~b}$ \\
\hline 0.5 & $7.23 \pm 0.40 \mathrm{~b}$ & $3.04 \pm 0.16 \mathrm{~b}$ & $0.33 \pm 0.01 \mathrm{c}$ \\
\hline 1 & $9.85 \pm 0.49 \mathrm{c}$ & $3.48 \pm 0.16 \mathrm{bc}$ & $0.34 \pm 0.0 \mathrm{c}$ \\
\hline 2 & $13.68 \pm 0.35 \mathrm{~d}$ & $3.63 \pm 0.13 \mathrm{~d}$ & $0.44 \pm 0.02 \mathrm{~d}$ \\
\hline 4 & $14.61 \pm 0.24 \mathrm{~d}$ & $4.69 \pm 0.14 \mathrm{~d}$ & $0.47 \pm 0.03 \mathrm{~d}$ \\
\hline F-test & $* *$ & $* *$ & $* *$ \\
\hline
\end{tabular}

Same letters in a column did not differ significantly at $\mathrm{p} \leq 0.05$ by

DMRT; ** indicate significant at 0.01 level of probability.

Table 4. Matrix of arsenic accumulation correlation coefficient among water, soil, straw and grain arsenic

\begin{tabular}{|c|c|c|c|c|c|}
\hline & & $\begin{array}{c}\text { Arsenic } \\
\text { added in } \\
\text { water } \\
(\mathrm{mg} / \mathrm{l}) \\
\end{array}$ & $\begin{array}{c}\text { Arsenic } \\
\text { in soil } \\
(\mathrm{mg} / \mathrm{kg})\end{array}$ & $\begin{array}{l}\text { Arsenic } \\
\text { in straw } \\
(\mathrm{mg} / \mathrm{kg})\end{array}$ & $\begin{array}{l}\text { Arsenic } \\
\text { in grain } \\
\text { (mg } / \mathrm{kg})\end{array}$ \\
\hline \multirow{2}{*}{$\begin{array}{c}\text { Arsenic } \\
\text { added in } \\
\text { water } \\
(\mathrm{mg} / \mathrm{l})\end{array}$} & $\begin{array}{c}\text { Pearson } \\
\text { Correlation } \\
\end{array}$ & 1 & $.900 * *$ & $.864 * *$ & $.804^{* *}$ \\
\hline & $\begin{array}{l}\text { Sig. (2- } \\
\text { tailed) }\end{array}$ & & .000 & .000 & .000 \\
\hline \multirow{2}{*}{$\begin{array}{c}\text { Arsenic } \\
\text { in soil } \\
(\mathrm{mg} / \mathrm{kg})\end{array}$} & $\begin{array}{c}\text { Pearson } \\
\text { Correlation }\end{array}$ & $.900^{* *}$ & 1 & $.919^{* *}$ & $.943^{* *}$ \\
\hline & $\begin{array}{l}\text { Sig. (2- } \\
\text { tailed) }\end{array}$ & .000 & & .000 & .000 \\
\hline \multirow{2}{*}{$\begin{array}{l}\text { Arsenic } \\
\text { in straw } \\
(\mathrm{mg} / \mathrm{kg})\end{array}$} & $\begin{array}{c}\text { Pearson } \\
\text { Correlation }\end{array}$ & $.864 * *$ & $.919 * *$ & 1 & $.921^{* *}$ \\
\hline & $\begin{array}{l}\text { Sig. (2- } \\
\text { tailed) }\end{array}$ & .000. & .000 & & .000 \\
\hline \multirow{2}{*}{$\begin{array}{l}\text { Arsenic } \\
\text { in grain } \\
(\mathrm{mg} / \mathrm{kg})\end{array}$} & $\begin{array}{c}\text { Pearson } \\
\text { Correlation } \\
\end{array}$ & $.804^{* *}$ & $.943^{* *}$ & $.921^{* *}$ & 1 \\
\hline & $\begin{array}{l}\text { Sig. (2- } \\
\text { tailed) }\end{array}$ & .000 & .000 & .000 & \\
\hline
\end{tabular}

** indicate correlation is significant at the 0.01 level (2-tailed). $\mathrm{N}=18$

\section{Conclusions}

From the overall observations of this study we may conclude that the trend of arsenic accumulation in Gangetic soil condition is as follows: irrigation water > soil $>$ straw $>$ grain. For rice cultivation the level of arsenic in irrigation water should be within 1mg/l. The findings of this research will help the farmers of Bangladesh for cultivating rice with lowest arsenic contamination.

\section{Acknowledgements}

This work is a part of Ph.D. research. We are grateful to SRDI, Rajshahi; BRRI, Rajshahi and BCSIR, Dhaka for their kind help during this research work. The financial help from the Ministry of Science and Technology, Government of Bangladesh is duly acknowledged.

\section{References}

[1] Food and Agricultural Organization of the United Nations (FAO), Food and Population: FAO Looks ahead, 2009.

[2] Dutta, A.K., Gope, P.S., Banik, S., Makhnoon, S., Siddiquee, M.A., Kabir, Y., "Antioxidant properties of ten high yielding rice varieties of Bangladesh,"Asian Pacific Journal of Tropical Biomedicine, 99-103. 2012.

[3] Bangladesh Bureau of Statistics (BBS), Household income and expenditure Survey, Dhaka, 2005.

[4] Murshid, K. A. S., Yunus, M., Ali, S.M.Z., Ahmed, N., Reemergence of food insecurity in Bangladesh: Instability in food production and prices, nature of food markets, impact and policy, National Food Policy Capacity Strengthening Programme, Dhaka, 2009.

[5] Hossain, M, "Pumping up production: Shallow tubewells and rice in Bangladesh," in D. Spielman, \& R. Pandya (Eds.), Millions fed: Proven successes in agricultural development, International Food Policy Research Institute, Washington, DC, 2009. 71-77.

[6] Baffes, J., Gautam, M., Is growth in Bangladesh's rice production sustainable? Policy Research Working Paper\#1666, World Bank, Washington DC, 1996.pp. 29

[7] Abedin, M.J. and Meharg, A.A., "Relative toxicity of arsenite and arsenate on germination and early seedling growth of rice (Oryza sativa L.),"Plant and Soil, 243, 57-66, 2002.

[8] Ahmed, K.M., Bhattacharya, P., Hasan, M. A., Akhter, S. H., Alam, S.M.M., Bhuyian, M. A. H., et al., "Arsenic enrichment in groundwater of alluvial aquifers in Bangladesh: An overview,"Applied Geochemistry, 19(2), 181-200, 2004.

[9] Hasan, M.A., Ahmed, K.M., Sracek, O., Bhattacharya, P., Brömssen, M.v., Broms, S., et al.,“Arsenic in shallow groundwater of Bangladesh: investigations from three different physiographic settings," Hydrogeology Journal,15,1507-1522,2007.

[10] Zheng, Y., van, G.A., Stute, M., Dhar, R., Mo, Z., Cheng, Z., et al., "Geochemical and hydrogeological contrast between shallow and deeper aquifers in two villages of Araihazar, Bangladesh: implication for deeper aquifers as drinking water sources", Geochim Cosmochim Acta, 69(22), 5203-5218, 2005.

[11] Bhattacharya, P., Ahmed, K.M., Hasan, M.A., Broms, S., Fogelström, J., Jacks, G., et al., "Mobility of arsenic in groundwater in a part of Brahmanbaria district, NE Bangladesh" in Naidu, R., Smith, E., Owens, G., Bhattacharya, P., Nadebaum, P (eds) Managing arsenic in the environment: from soil to human health, CSIRO,Melbourne, Australia,95-115,2006.

[12] Rahman, M.A., Hasegawa, H., Rahman, M.M., Islam, M.N., Miah, M.A.M., Tasmin, A., "Arsenic Accumulation in Rice (Oryza sativa L.) Varieties of Bangladesh: A Glass House Study,” Water Air Soil Pollution, 185, 53-61, 2007.

[13] Bhattacharya, P., Samal, A.C., Majumdar, J., Santra, S.C., "Accumulation of arsenic and its distribution in rice plant (Oryza sativa L.) in Gangetic West Bengal, India,” Paddy Water Environment, 8, 63-70, 2010.

[14] Lu, Y., Adomako, E.E., Solaiman, A.R.M., Islam, M.R., Deacon, C., Williams, P.N., Rahman, .K.M.M., Meharg, A.A., "Baseline soil variation is a major factor in arsenic accumulation in Bengal Delta paddy rice," Environmental Science \& Technology, 43, 1724-1729, 2009.

[15] Norton, G.J., Duan, G., Dasgupta, T., Islam, M.R., Lei, M., Zhu, Y., et al., "Environmental and genetic control of arsenic accumulation and speciation in rice grain: comparing a range of common cultivars crown in contaminated sites across Bangladesh, China, and India," Environmental Science \& Technology, 43, 8381-8386, 2009.

[16] Alam, M.Z., Rahman, M.M.,“Accumulation of arsenic in rice plant from arsenic contaminated irrigation water and effect on nutrient content,"in Proceedings of BUET-UNU International 
symposium of fate of arsenic in the environment, Dhaka, Bangladesh,2003, 131-135.

[17] Duxbury, J.M., Mayer, A.B., Lauren, J.G., "Food chain aspects of arsenic contamination in Bangladesh: Effects on quality and productivity of rice," Journal of Environmental Science and Health, 38, 61-69.

[18] Daum, D., Bogdan, K., Schenk, M.K., Merkel, D., “Influence of the field water management on accumulation of arsenic and cadmium in paddy rice," Developments in Plant and Soil Sciences, 92, 290-291.

[19] Rahman, M.A., Hasegawa, H., Rahman, M.M., Rahman, M.A. and Miah, M.A.M., "Accumulation of arsenic in tissues of rice plant (Oryza sativa L.) and its distribution in fractions of rice grain”, Chemosphere,.69,.942-948.

[20] Rahman, M.A., Rahman, M.M., Miah, M.A.M., Khaled, H.M., "Influence of soil arsenic concentrations in rice (Oryza sativa L.)," Journal of Sub-tropical Agricultural Research Developement, 2(3), 24-31.

[21] Abedin, M.J., Cotter-Howells, J., and Meharg, A.A, “Arsenicuptake and accumulation in rice (Oryza sativa L.) irrigated with contaminated water, Plant and Soil, 240, 311-319, 2002

[22] Ahsan, D.A., DelValls, T.A. and Blasco, J., "Distribution of Arsenic and Trace Metal in the Floodplain Agricultural Soil of Bangladesh,"Bulletin of Environmental Contamination \& Toxicology, 82, 11-15, 2009.
[23] Islam, M.R., Islam, S., Jahiruddin, M., Islam, M.A., "Effects of irrigation water arsenic in the rice-rice cropping system," Journal of Biological Science,. 4, 542-546, 2004.

[24] Tsutsumi, M., "Intensification of arsenic toxicity to paddy rice by hydrogen sulphides and ferrous iron I. Induction of bronzing and accumulation in rice by arsenic," Soil Science and Plant Nutrition, 26, 561-569, 1980.

[25] Panaullah, G.M., Alam, T., Hossain, M.B., Loeppert, R.H., Lauren, J.G., Meisner, C.A., Ahmed, Z.U., Duxbury, J.M., "Arsenic toxicity to rice (Oryza sativa L.) in Bangladesh,” Plant and Soil, 317(1), 31-39, 2009.

[26] Azad, M.A.K., Islam, M.N., Alam, A., Mahmud, H., Islam, M.A., Karim, M.R and Rahman, M., "Arsenic uptake and phytotoxicity of T-aman rice (Oryza sativa L.) grown in the As amended soil of Bangladesh,” Environmentalist, 29, 436-440, 2009.

[27] Meharg, A.A. and Rahman, M.M., "Arsenic contamination of Bangladesh paddy field soils: Implications for rice contribution to arsenic consumption," Environmental Science \& Technology, 37, 229-234, 2003.

[28] Schoof, R.A., Yost, L.J., Crecelius, E., Irgolic, K., Goessler, W., Guo, H.R and. Greene, H., "Dietary arsenic intake in Taiwanese districts with elevated arsenic in drinking water," Human Ecological Risk Assesment, 4, 117-135, 1998. 